\title{
THE \\ INDONESIAN ECONOMY \\ IN TRANSITION
}


The ISEAS - Yusof Ishak Institute (formerly Institute of Southeast Asian Studies) was established as an autonomous organization in 1968. It is a regional centre dedicated to the study of socio-political, security and economic trends and developments in Southeast Asia and its wider geostrategic and economic environment. The Institute's research programmes are the Regional Economic Studies (RES, including ASEAN and APEC), Regional Strategic and Political Studies (RSPS), and Regional Social and Cultural Studies (RSCS).

ISEAS Publishing, an established academic press, has issued more than 2,000 books and journals. It is the largest scholarly publisher of research about Southeast Asia from within the region. ISEAS Publishing works with many other academic and trade publishers and distributors to disseminate important research and analyses from and about Southeast Asia to the rest of the world. 


\section{THE \\ INDONESIAN ECONOMY IN TRANSITION}

Policy Challenges in the Jokowi Era and Beyond

HAL HILL・SIWAGE DHARMA NEGARA 
First published in Singapore in 2019 by

ISEAS Publishing

30 Heng Mui Keng Terrace

Singapore 119614

E-mail: publish@iseas.edu.sg

Website: <http://bookshop.iseas.edu.sg>

All rights reserved. No part of this publication may be reproduced, stored in a retrieval system, or transmitted in any form or by any means, electronic, mechanical, photocopying, recording or otherwise, without the prior permission of the ISEAS - Yusof Ishak Institute.

(C) 2019 ISEAS - Yusof Ishak Institute, Singapore

The responsibility for facts and opinions in this publication rests exclusively with the authors and their interpretations do not necessarily reflect the views or the policy of the publisher or its supporters.

\section{ISEAS Library Cataloguing-in-Publication Data}

Hill, Hal, 1948-

The Indonesian Economy in Transition : Policy Challenges in the Jokowi Era and Beyond / Hal Hill and Siwage Dharma Negara.

1. Indonesia-Economic policy.

2. Indonesia-Economic conditions-1997-

3. Joko Widodo, 1961-

4. Indonesia-Politics and government-1998-

I. Negara, Siwage Dharma.

II. Title.

HC447 H642

ISBN 978-981-4843-06-5 (soft cover)

ISBN 978-981-4843-10-2 (e-book, PDF)

Typeset by Superskill Graphics Pte Ltd

Printed in Singapore by Mainland Press Pte Ltd 